\title{
OPTIMIZATION OF THE PARAMETERS FOR THE SURFACTANT-ADDED EDM OF A Ti-6Al-4V ALLOY USING THE GRA-TAGUCHI METHOD
}

\author{
OPTIMIZACIJA POVRŠINSKO AKTIVNIH MEŠANIH EDM \\ PARAMETROV NA Ti-6Al-4V ZLITINI Z UPORABO \\ GRA-TAGUCHI METODE
}

\author{
Murahari Kolli, Kumar Adepu \\ Department of Mechanical Engineering, National Institute of Technology, Warangal, Telangana, India \\ kmhari.nitw@gmail.com \\ Prejem rokopisa - received: 2014-09-30; sprejem za objavo - accepted for publication: 2015-03-23
}

doi:10.17222/mit.2014.249

\begin{abstract}
In this research, the Taguchi technique was applied to determine the optimum process parameters for the electrical discharge machining (EDM) of a titanium alloy with an added surfactant. The surfactant added to the dielectric fluid played an important role in the discharge gap, increasing the conductivity and suspending debris particles in the dielectric fluid, reducing abnormal discharge conditions of the machine and improving the overall machining efficiency. The performance characteristics were the material-removal rate $(M R R)$ and the surface roughness $(S R)$, which were experimentally explored for various input parameters such as the discharge current, the pulse-on time, the pulse-off time and the surfactant concentration in the dielectric fluid. The optimum setting of the parameters was verified through planned and conducted experiments and analysed using the Taguchi technique. Further, a multi-response optimisation was carried out, maximising the $M R R$ and minimising the $S R$, using the Grey relational analysis (GRA). It was observed that the pulse-on time, the discharge current, the pulse-off time and the surfactant concentration contribute significantly to the multi-response optimisation. Conformation test results showed an improvement in the MRR by $20.69 \%$ and in the SR by $11.09 \%$. A scanning-electron-microscope (SEM) analysis was conducted to study the recast layer that evolved during the electrical discharge machining process and the topography of surfaces was also observed.

Keywords: surfactant, Ti-6Al-4V alloy, Grey-Taguchi method, material-removal rate, surface roughness, recast-layer thickness
\end{abstract}

V članku je uporabljena Taguchi metoda za določanje optimalnih parametrov procesa površinsko aktivne elektroerozije (EDM) na titanovi zlitini. Površinsko aktivne snovi, dodane dielektrični tekočini, igrajo pomembno vlogo pri razelektritveni reži, kar poveča prevodnost in ustavi delce v dielektrični tekočini, zmanjša neobičajne razelektritve pri obdelavi in na splošno poveča učinkovitost obdelave. Značilnosti zmogljivosti sta hitrost odstranjevanja materiala $(M R R)$ in hrapavost površine $(S R)$, ki sta bili eksperimentalno uporabljeni za različne vhodne parametre, kot je: tok razelektritve, trajanje impulza, trajanje prekinitve in koncentracija površinsko aktivne snovi v dielektrični tekočini. Optimalna postavitev parametrov je bila preizkušena $\mathrm{z}$ načrtovanimi preizkusi in analizirana s Taguchi metodo. Izvršena je bila optimizacija z več odgovori, to je maksimiranje $M R R$ in minimiziranje $S R$ s pomočjo uporabe Grey relacijske analize (GRA). Ugotovljeno je, da tok razelektritve, trajanje pulza, čas brez pulza in koncentracija površinsko aktivne snovi, močno prispevajo k optimizaciji. Rezultati potrditvenih preizkusov so pokazali izboljšanje $M R R$ za 20,69\% in $S R$ za $11,09 \%$. Z vrstičnim elektronskim mikroskopom (SEM) je bila izvršena analiza (SEM) pretaljenega sloja, ki se je razvil med postopkom elektroerozije, opazovana pa je bila tudi topografija površine.

Ključne besede: površinsko aktivne snovi, Ti-6Al-4V zlitina, Grey-Taguchi metoda, hitrost odstranjevanja materiala, hrapavost, debelina nataljene plasti

\section{INTRODUCTION}

The usage of and demand for the Ti-6Al-4V alloy is on an increase day by day because of its high strength, low weight ratio, high corrosion resistance, resistance to high temperature and high toughness. This makes it the appropriate alloy for surgery, medicine, aerospace, the automotive industry, chemical plants, pressure vessels and power generation. It is used to manufacture propeller shafts, riggings and other parts of boats. It is also used to create artificial hips, pins for setting the bones and other biological implants due to its excellent biocompatibility. Its application also includes aircraft-turbine components, aircraft structural components, aerospace fasteners and high-performance automotive parts. ${ }^{1,2}$

Ti-6Al-4V is one of the materials difficult to machine due to its properties. It chemically reacts with almost all cutting-tool materials. Its low thermal conductivity and low modulus of elasticity reduce the machinability. ${ }^{3}$ Low cutting speeds, high feed rates, a huge quantity of cutting fluids, sharp tools and a rigid set-up are essential for the conventional machining of Ti-6Al-4V. This makes its conventional machining uneconomical. EDM is one of the advanced manufacturing processes, with which a Ti-6Al-4V alloy can be machined economically and efficiently. ${ }^{4}$

In modern manufacturing industries, EDM is one of the most popular non-conventional machining processes, used to produce dies, moulds or process ceramics, etc. Tough and hard metals that are generally used in the industries, such as aerospace, automotive and surgical applications, can be machined easily using EDM, taking into account various material properties, such as the elec- 
trical and thermal conductivity. EDM is a thermoelectric machining process, in which the electrode and the workpiece do not come into direct contact, which eliminates the mechanical residual stresses and chatter or vibration problems during the machining. ${ }^{5}$ In an EDM process, the dielectric fluid plays a vital role, affecting the materialremoval rate and the surface integrity of the machined surface. The vital tasks of the working fluid are transporting sediment particles, enhancing the discharge-energy density of the plasma zone and cooling the electrodes. ${ }^{6}$ It has been noticed from a wide literature survey that most of the researchers focused on reducing the surface roughness and increasing the material-removal rate using kerosene, water and water-oil emulsions of different materials. Very few researchers studied the effect of a surfactant added to EDM. A scarce amount of research work was done on the surfactant added to the EDM oil in the conventional EDM of the titanium alloy.

A surfactant is added into the dielectric fluid for a better circulation in the discharge gap and to avoid particle agglomeration (debris and tar). During the machining process, surfactant molecules enter the discharge gap, thereby breaking down the voltage easily, reducing the insulating strength by increasing the discharge gap and passage and ensuring an even discharge distribution during the machining process. As a result, the process becomes more stable, thereby improving the machining efficiency, reducing the surface roughness and increasing the material-removal rate. ${ }^{7-9}$

A considerable amount of work on EDM of titanium alloy Ti-6Al-4V was reported by the researchers. Chen et al. ${ }^{10}$ compared the influences of kerosene and distilled water. It was noticed that the material-removal rate was increased and the relative electrode-wear rate was decreased when distilled water was used as the dielectric, when compared to kerosene. Ho et al. ${ }^{11}$ investigated the use of a powder-metallurgy (PM) compacted electrode. It was observed that the PM electrode was more alloyed than the solid electrode. The thickness of the recast layer was increased when the PM electrode and positive polarity were used.

Hascalik and Caydas ${ }^{12}$ analysed the effects of copper, graphite and aluminum electrodes. The material-removal rate was increased in the case of the graphite electrode and the surface roughness was reduced with the aluminum electrode, compared to other electrodes. Caydas and Hascalik. ${ }^{13}$ developed a model of the electrode wear and recast-layer thickness using the response surface methodology. It was observed that the values predicted by the model reasonably matched the experimental values. Fonda et al. ${ }^{14}$ studied the effects of the properties of Ti-6Al-4V on EDM. It was observed that the optimum duty factor was $7 \%$ as far as the productivity and quality of an EDMed surface were concerned.

Abdulkareem et al. ${ }^{15}$ analysed the effect of cryogenic cooling on the copper-electrode wear and the surface roughness of Ti-6Al-4V. It was observed that the electrode wear reduced remarkably and the surface finish improved due to cryogenic cooling. Bozdana et al. ${ }^{16}$ compared the performance of brass-copper tubular electrodes with copper electrodes. It was observed that the material-removal rate increased with decreased electrode wear when brass electrode was used, as compared to the copper electrode. Khan et al. ${ }^{17}$ developed a singleorder mathematical model for correlating the parameters and performance characteristics during EDM. It was observed that as the peak current increased, the surface roughness increased. The combination of a high-peak current and long pulse-on time deteriorated the surface roughness. Rahman ${ }^{18}$ developed an artificial-intelligence model to predict the optimum parameters. It was found that the developed model was within the limits of tolerable errors with respect to experimental results. Kolli and Kumar ${ }^{19}$ investigated the effects of the additives added to the dielectric fluid on the EDM of a titanium alloy. Their experiments were conducted by varying the concentration of the additives and the discharge current to measure their effects on the $M R R$, $S R$ and $T W R$. It was observed that the $M R R$ increased with an increase in the discharge current and the surfactant concentration.

Multi-response optimisation has become an increasingly important area in the modern manufacturing industry to satisfy the customer's strict requirement for the overall quality improvement in the process and machined components, Jeyapaul et al. ${ }^{20}$ and Kao et al. ${ }^{21}$ considered the Taguchi method and the grey relational analysis to optimize the multiple-performance characteristics of the EDM of the Ti-6Al-4V alloy. Kerosene was taken as the dielectric fluid and electrolytic copper as the electrode. It was observed that the optimized parameters increased the MRR by $12 \%, E W R$ by $15 \%$ and $S R$ by $19 \%$, when applying the GRA technique. Tang and $\mathrm{Du}^{22}$ employed the multi-objective optimization technique for the grey EDM of the Ti-6Al-4V alloy. In this study, tap water was used as the dielectric fluid and tungsten copper as the electrode of a $10 \mathrm{~mm}$ diameter. The input process parameters included the discharge current, the open-circuit voltage, the lifting time, the pulse-on time and the pulse-off time. The machining performance parameters like the $E W R$, the $M R R$ and the $S R$ were estimated. The authors concluded that when the multi-optimization technique was included in the Taguchi method it increased the machining performance parameters, i.e., the $M R R$ by $2 \%$, the $E W R$ by $59 \%$ and the $S R$ by $4 \%$.

Lin et al. ${ }^{23}$ applied the Grey-Taguchi technique to optimise the EDM parameters for a titanium alloy with kerosene as the dielectric fluid. The effects of the process parameters such as the peak current, the pulse-on time, the pulse-off time and the gap voltage on their performance parameters like the electrode depletion (ED), the $M R R$ and the overcut were studied. It was observed from the final results that the discharge current 
and the pulse-on time were the most significant parameters of the EDM using the Grey-Taguchi method. In addition, it was mentioned that the Grey-Taguchi method is highly suitable for the optimization of the ED, the $M R R$ and the overcut.

In this experimental study, the dielectric fluid with an added surfactant used for the electrical discharge machining of a titanium alloy was investigated and the characteristics were optimized with the Grey-Taguchi technique. The process parameters such as the discharge current, the pulse-on time, the pulse-off time and the surfactant concentration were varied. The optimum setting of the parameters was verified through the planned experiments, conducted and analysed with the Taguchi technique. The material-removal rate $(M R R)$ and the surface roughness $(S R)$ were considered as the performance characteristics. Further study was carried out to observe the influence of the process parameters on the presence of the recast layer on the machined surfaces using SEM and also to observe the topography of surfaces.

\section{EXPERIMENTAL SET-UP}

The experiments were performed on a Formatics EDM-50 die-sinking machine mounted on a custom-built dielectric-cycling system. The electrode was fed downwards, under the DC servo control, into the workpiece. Surfactant-added (Span 20) spark-erosion 450 EDM oil was used as the dielectric fluid for the machining, used in die-sinking machines for a high machining speed and a good surface finish. The surfactant was added in a certain amount into the dielectric fluid and continuously stirred in order to maintain a uniform distribution. The homogenously mixed dielectric fluid was pumped into the machining region using side flushing. Surfactant chemical properties are presented in Table 1. The experiments were conducted with a reverse-polarity electrode. A electrolytic copper with a diameter of $14 \mathrm{~mm}$ and a length of $70 \mathrm{~mm}$ was selected as the electrode. A workpiece with a length of $100 \mathrm{~mm}$, a width of $50 \mathrm{~mm}$ and a thickness of $5 \mathrm{~mm}$ was employed. Each experiment was conducted for $30 \mathrm{~min}$.

Table 1: Surfactant properties

Tabela 1: Lastnosti površinsko aktivnih snovi

\begin{tabular}{|l|c|}
\hline \multicolumn{1}{|c|}{ Property } & Quantity \\
\hline Chemical formula & $\mathrm{C}_{18} \mathrm{H}_{34} \mathrm{O}_{6}$ \\
\hline Molecular weight & $346.47(\mathrm{~g} / \mathrm{mol})$ \\
\hline Density & $1.032 \mathrm{~g} / \mathrm{mL}$ at $25^{\circ} \mathrm{C}(\mathrm{L})$ \\
\hline Flash point & $>230{ }^{\circ} \mathrm{F}\left(110^{\circ} \mathrm{C}\right)$ \\
\hline Relative index & $\mathrm{n} 20 / \mathrm{D} 1.4740(\mathrm{~L})$ \\
\hline$H L B$ value & 8.6 \\
Water content & $<1.5(\%)$ \\
\hline Acid value & $4-8$ \\
\hline Heavy metal & $9.5-10.0(\mathrm{~L} / \%)$ \\
\hline Saponification value & $158-170$ \\
\hline
\end{tabular}

Prior to the machining, the workpiece and the electrode were cleaned and polished. The workpiece was firmly clamped in the vice and immersed in the dielectric fluid. The die-sinking EDM-machine experimental set-up is shown in Figure $\mathbf{1}$ and the titanium-alloy chemical composition and properties are shown in Tables 2 and 3. The weight of the workpiece and the electrode tool was measured using a digital weighing balance

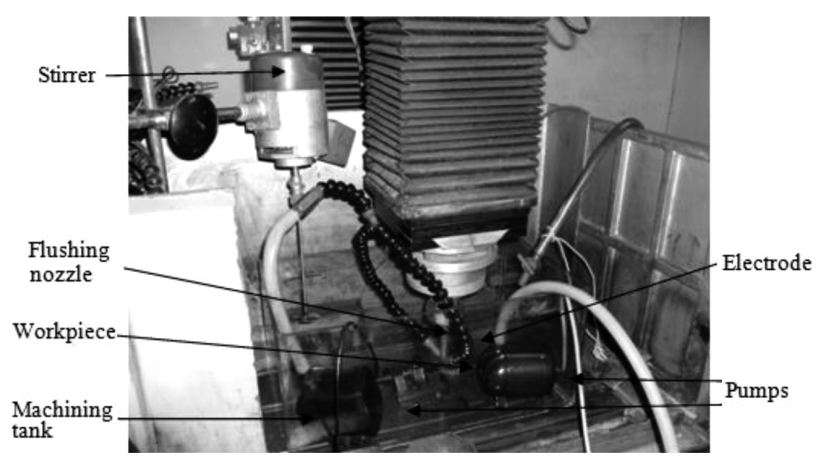

Figure 1: Modified experimental set-up

Slika 1: Spremenjen eksperimentalni sestav

Table 2: Chemical composition of Ti-6Al-4V alloy

Tabela 2: Kemijska sestava Ti-6Al-4V zlitine

\begin{tabular}{|c|c|c|c|c|c|c|c|c|}
\hline $\begin{array}{c}\text { Ele- } \\
\text { ment }\end{array}$ & $\mathrm{C}$ & $\mathrm{Al}$ & $\mathrm{V}$ & $\mathrm{N}$ & $\mathrm{O}$ & $\mathrm{Fe}$ & $\mathrm{H}$ & $\mathrm{Ti}$ \\
\hline$\%$ & $\begin{array}{c}\text { Max. } \\
0.014\end{array}$ & 6.07 & 4.02 & 0.0036 & 0.1497 & 0.03 & 0.0115 & $\begin{array}{c}\text { Bal- } \\
\text { ance }\end{array}$ \\
\hline
\end{tabular}

Table 3: Properties of Ti-6Al-4V alloy

Tabela 3: Lastnosti zlitine Ti-6Al-4V

\begin{tabular}{|l|c|}
\hline \multicolumn{1}{|c|}{ Property } & Values \\
\hline Hardness $(\mathrm{HRC})$ & $32-34$ \\
\hline Melting point $\left({ }^{\circ} \mathrm{C}\right)$ & $1649-1660$ \\
\hline Density $\left(\mathrm{g} / \mathrm{cm}^{3}\right)$ & 4.43 \\
\hline Ultimate tensile strength $(\mathrm{MPa})$ & $897-950$ \\
\hline Thermal conductivity $(\mathrm{W} / \mathrm{m} \mathrm{K})$ & $6.7-6.9$ \\
\hline Specific heat $(\mathrm{J} / \mathrm{kg} \mathrm{K})$ & 560 \\
\hline $\begin{array}{l}\text { Mean coefficient of thermal expansion } \\
(\mathrm{W} / \mathrm{kg} \mathrm{K})\end{array}$ & $8.6 \times 10^{-6}$ \\
\hline Volume electrical resistivity $(\Omega \mathrm{cm})$ & 170 \\
\hline Elastic modulus $(\mathrm{GPa})$ & $113-114$ \\
\hline
\end{tabular}

Table 4: Experimental settings

Tabela 4: Eksperimentalne nastavitve

\begin{tabular}{|l|c|}
\hline \multicolumn{1}{|c|}{ Working parameters } & Description \\
\hline Workpiece material & Ti-6Al-4V \\
\hline Size of work piece & \begin{tabular}{c}
$100 \times 50 \times 5 \mathrm{~mm}$ \\
\hline Electrode material
\end{tabular} \\
\hline Size of electrode & $\phi 14 \times 70 \mathrm{~mm}$ \\
\hline Electrode polarity & $\begin{array}{c}\text { Spark erosion } 450 \mathrm{EDM} \text { oil } \\
+ \text { surfactant }\end{array}$ \\
\hline Dielectric fluid & $110 \mathrm{~V}$ \\
\hline Discharge open voltage & $65 \mathrm{~V}$ \\
\hline Discharge gap voltage & $0.75 \mathrm{MPa}$ \\
\hline Flushing pressure & $30 \mathrm{~min}$ \\
\hline Machining time & \\
\hline
\end{tabular}


(manufactured by CITIZEN) before and after the machining to calculate the $M R R$. The surface roughness of the machined workpieces was measured using Handysurf equipment. The range of each factor was taken based on the capability of the machine and the data from the literature, and preliminary experiments were conducted to that effect. ${ }^{19,24,25}$ The process parameters and experimental conditions considered are listed in Tables $\mathbf{4}$ and 5, respectively.

Table 5: Process parameters Tabela 5: Parametri procesa

\begin{tabular}{|c|c|c|c|c|c|}
\hline Symbols & Control factors & Level 1 & Level 2 & Level 3 & Units \\
\hline A & $\begin{array}{c}\text { Discharge } \\
\text { current }\left(I_{\mathrm{p}}\right)\end{array}$ & 10 & 15 & 20 & $\mathrm{~A}$ \\
\hline $\mathrm{B}$ & $\begin{array}{c}\text { Pulse-on time } \\
\left(T_{\text {on }}\right)\end{array}$ & 25 & 45 & 65 & $\mu \mathrm{s}$ \\
\hline $\mathrm{C}$ & $\begin{array}{c}\text { Pulse-off time } \\
\left(T_{\text {off }}\right)\end{array}$ & 24 & 36 & 48 & $\mu \mathrm{s}$ \\
\hline $\begin{array}{c}\text { Surfactant } \\
\text { concentration } \\
(S C)\end{array}$ & 0.25 & 0.50 & 0.75 & $\mathrm{~g} / \mathrm{L}$ \\
\hline
\end{tabular}

\subsection{Taguchi method}

The Taguchi method is very effective when dealing with responses influenced by many parameters. It is a simple, efficient and systematic approach for determining optimum process parameters. It is a powerful tool for designing experiments, drastically reducing the number of experiments required for modelling and optimising the responses. Also, it saves lot of time and reduces the experimental cost. The Taguchi method is devised for process optimization and identification of the optimum levels of the process parameters for given responses. ${ }^{26-28}$ In Taguchi method, the experimental values of various responses are further transformed to the signal-to-noise $(S / N)$ ratio. The response that is to be maximized is called the 'higher the better' response and the one that is to be minimized is called the 'lower the better' response. The Taguchi method uses the $S / N$ ratio to measure the deviation of a response from the mean value. $S / N$ ratios for 'higher the better' and 'lower the better' characteristics are calculated using Equations (1) and (2), respectively:

$$
\begin{aligned}
& \eta=-10 \lg _{10}\left[\frac{1}{n} \sum_{i=1}^{n} \frac{1}{y_{i}^{2}}\right] \\
& \eta=-10 \lg _{10}\left[\frac{1}{n} \sum_{i=1}^{n} y_{i}^{2}\right]
\end{aligned}
$$

where $\eta$ denotes the $S / N$ ratio of experimental values, $y_{i}$ represents the experimental value of the $i^{\text {th }}$ experiment and $\mathrm{n}$ is the total number of experiments. In the present study, the Taguchi method was applied to experimental data using the MINITAB 16 software. The number of process parameters considered under this study is four and the level of each factor is three. The degree of freedom of all four factors is eight. Hence, the $\mathrm{L}_{9}\left(3^{4}\right)$ ortho- gonal array is selected. Each condition of the experiment was repeated three times in order to reduce the noise/error effects. The quality characteristics of the $M R R$ and the $S R$ of the titanium alloy, evaluated for all the experimental results are listed in Table 6. The optimum element combinations were verified using the statistical analysis of variance (ANOVA).

\subsection{Grey relational analysis (GRA)}

The Grey relational analysis (GRA) was initially introduced by Dr. Deng in 1982. GRA has uncertain relations between one main factor and multi-input factors in a given system. It is an impact-measurement method of the grey-system theory. ${ }^{29}$ The Taguchi method, along with GRA, is applied to optimize the EDM process parameters with multi-performance characteristics, which include the following steps:

1. Identifying the performance characteristics and EDM process parameters to be evaluated.

2. Finding out the number of levels for further EDM control parameters.

3. Selecting the suitable OA layout (orthogonal array).

4. Conducting OA-layout experiments.

5. Normalizing the experimental results, i.e., the measured features of the performance characteristics ranging from 0 to 1 , usually known as the Grey relational generation.

6. Calculating the Grey relational co-efficient $(\xi)$ based on the experimental results.

7. Obtaining the grey relational grade for selected performance parameters by averaging the corresponding grey relational coefficients.

8. Analysing the experimental results by using the Grey relational grade and statistical ANOVA.

9. Selecting the optimum level of EDM process parameters for maximizing the overall Grey relational grade.

10. Verifying the optimum EDM process parameters through the conformation test.

During the Grey relational generation, the material-removal rate $(M R R)$ corresponding to the higher the better $(H B)$ criterion can be expressed as:

$$
x_{i}(k)=\frac{y_{i}(k)-\min y_{i}(k)}{\max y_{i}(k)-\min y_{i}(k)}
$$

The surface roughness $(S R)$ should follow the smaller the better $(L B)$ criterion, which can be expressed as:

$$
x_{i}(k)=\frac{\max y_{i}(k)-y_{i}(k)}{\max y_{i}(k)-\min y_{i}(k)}
$$

However, if a definite target value is to be achieved, the original sequence is normalised in the following form:

$$
x_{i}(k)=1-\frac{\left|y_{i}(k)-O B\right|}{\max \left\{\max y_{i}(k)-O B, O B-\min y_{i}(k)\right\}}
$$


where $O B$ is the target value.

Alternatively, the original sequence can be simply normalised using the most basic methodology, i.e., the values of the original sequence are divided by the first value of the sequence:

$$
x_{i}(k)=\frac{y_{i}(k)}{y_{i}(1)}
$$

where $x_{\mathrm{i}}(k)$ is the value after the grey relational generation (data processing), $y_{\mathrm{i}}(k)$ is the original sequence, $\max y_{\mathrm{i}}(k)$ is the largest value of $y_{\mathrm{i}}(k)$ for the $k^{\text {th }}$ response, and $\min y_{\mathrm{i}}(k)$ is the smallest value of $y_{\mathrm{i}}(k)$, being the desired value. ${ }^{29,30}$ The ideal sequence of responses is $y_{\mathrm{i}}(k)(k=1,2,3 \ldots, m)$.

Further, during the data pre-processing, the Grey relational coefficient is calculated to express the relationship between the ideal and actual normalised experimental results. The Grey relational coefficient can be expressed as follows:

$$
\xi_{i}(k)=\frac{\Delta_{\text {min }}+\zeta \Delta_{\max }}{\Delta_{0 i}(k)+\zeta \Delta_{\max }}
$$

where $\Delta_{0 i}(k)$ is the deviation sequence of the reference sequence $x_{\mathrm{i}}(k)$ and the comparability sequence $y_{i}(k)$.

$$
\Delta_{0 i}=\left\|x_{0}(k)-x_{i}(k)\right\|=\text { difference of the absolute value }
$$

between $x_{0}(k)$ and $x_{i}(k)$;

$\zeta=$ distinguishing coefficient $(0 \sim 1)$

$$
\begin{aligned}
& \Delta_{\text {min }}=\forall j^{\min } \in i \forall k^{\min }\left\|x_{0}(k)-x_{i}(k)\right\| \\
& \Delta_{\text {max }}=\forall j^{\max } \in i \forall k^{\max }\left\|x_{0}(k)-x_{i}(k)\right\|
\end{aligned}
$$

After obtaining the Grey relational coefficient, its average is calculated to obtain the grey relational grade. The Grey relational grade $(\gamma)$ is defined as follows: ${ }^{31}$

$$
\gamma_{i}=\frac{1}{n} \sum_{k=1}^{n} \zeta_{i}(k)
$$

The GRA also indicates the degree of influence that the comparability sequence can exert over the reference sequence. Therefore, if a particular comparability sequence is more important than the other comparability sequence for the reference sequence, then the Grey relational grade for that comparability sequence and the reference sequence is higher than the other Grey relational grade. ${ }^{31,32}$ With this technique, both the comparability sequence and the reference sequence are of equal preference.

\section{RESULTS AND DISCUSSION}

\subsection{Effects of the parameters on the MRR}

Table 6 shows the values of $M R R$ s and their $S / N$ ratios. Table 7 has the corresponding ANOVA results where the contributions of individual parameters are calculated. It can be observed that the discharge current with a contribution of $90.51 \%$, the pulse-on time with a contribution of $7.95 \%$ and the surfactant with a contribution of $1.01 \%$ significantly affect the $M R R$ at the 95 $\%$ confidence interval, but the pulse-off time makes an insignificant contribution to the $M R R$.

Table 6: Experimental layout $\mathrm{L}_{9}\left(3^{4}\right) \mathrm{OA}$ and results for $S / N$ ratios for $M R R$ s and $S R$ s

Tabela 6: Eksperimentalna postavitev $\mathrm{L}_{9}\left(3^{4}\right) \mathrm{OA}$ in rezultati razmerja $S / N, M R R$ in $S R$

\begin{tabular}{|c|c|c|c|c|c|c|c|c|}
\hline Ex. no & $(\mathrm{A})$ & $(\mathrm{B})$ & $(\mathrm{C})$ & $(\mathrm{D})$ & $M R R$ & $\begin{array}{c}S / N \\
\text { ratio }\end{array}$ & $S R$ & $S / N$ ratio \\
\hline 1 & 10 & 25 & 24 & 0.25 & 1.108 & 0.893 & 2.51 & -7.958 \\
\hline 2 & 10 & 45 & 36 & 0.50 & 1.260 & 2.010 & 2.75 & -8.786 \\
\hline 3 & 10 & 65 & 48 & 0.75 & 1.461 & 3.292 & 3.19 & -10.076 \\
\hline 4 & 15 & 25 & 36 & 0.75 & 1.755 & 4.887 & 2.65 & -8.464 \\
\hline 5 & 15 & 45 & 48 & 0.25 & 1.917 & 5.652 & 3.57 & -11.053 \\
\hline 6 & 15 & 65 & 24 & 0.50 & 2.216 & 6.911 & 3.66 & -13.271 \\
\hline 7 & 20 & 25 & 48 & 0.50 & 2.321 & 7.315 & 3.23 & -10.184 \\
\hline 8 & 20 & 45 & 24 & 0.75 & 2.514 & 8.008 & 4.22 & -12.465 \\
\hline 9 & 20 & 65 & 36 & 0.25 & 2.530 & 8.062 & 4.48 & -13.029 \\
\hline
\end{tabular}

Table 7: ANOVA of means for $M R R \mathrm{~s}$

Tabela 7: ANOVA sredstva za $M R R$

\begin{tabular}{|c|c|c|c|c|}
\hline Parameters & $\begin{array}{c}\text { Degree of } \\
\text { freedom } \\
(D F)\end{array}$ & $\begin{array}{c}\text { Sum of } \\
\text { squares }(S S)\end{array}$ & $\begin{array}{c}\text { Mean sum } \\
\text { of squares } \\
(M S S)\end{array}$ & $\begin{array}{c}\% \text { contri- } \\
\text { bution }\end{array}$ \\
\hline A & 2 & 50.835 & 25.417 & 90.51 \\
\hline B & 2 & 4.466 & 2.233 & 7.95 \\
\hline C & 2 & 0.292 & 0.146 & 0.53 \\
\hline D & 2 & 0.571 & 0.285 & 1.01 \\
\hline Total & 8 & 56.164 & & 100.00 \\
\hline
\end{tabular}

The main response plot of the $S / N$ ratio in Figure 2 shows that the $M R R$ increases with an increase in the discharge current. It indicates that the discharge current is the leading impact factor for the MRR. The discharge current mainly influences the discharge density available in the discharge gap. To improve the discharge current, spark energy is increased, which results in a higher discharge density. This eventually heats the workpiece, thus increasing the $M R R$ at increased discharge-current conditions. ${ }^{21}$ The pulse-on time controls the pulse duration of the time, for which the current is supplied to the flow per cycle. The pulse-on time increases with an increase in the MRR. Due to higher discharge energy on the workpiece, more material is melted and evaporated in the machined zone. During the pulse-off time, no material is removed from the workpiece as there is no current supply to the workpiece and the existing material on the machined surface of the workpiece is removed. ${ }^{33}$

Another observation from the present experiment is that an increase in the surfactant concentration increases the MRR. The conductivity of the dielectric fluid is increased by adding non-polar surfactant, which results in a shorter bridging time and a higher electrical-discharge efficiency, which finally results in an increase in the MRR. An addition of the surfactant to the EDM oil retards the agglomeration of debris, carbon dregs due to electrostatic forces or Van der Waals forces during ma- 


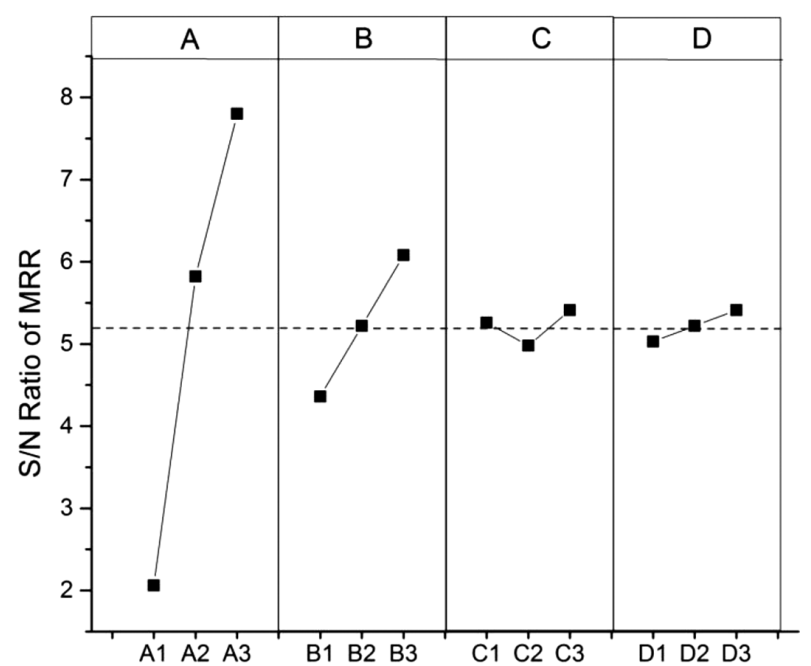

Figure 2: Main-effect plot for MRR

Slika 2: Diagram glavnega učinka MRR

chining. After that the dielectric-fluid behaviour in the inter-electrode gap is changed, minimizing the bridge effect that leads to a better distribution of discharge energy, resulting in an overall increase in the $M R R .^{34,35}$

\subsection{Effects of the parameters on the $S R$}

The average values of the $S R$ for each experiment and their respective $S / N$ ratio values are presented in Table 6. Figure 3 shows $S R$ response curves, representing individual effects of discharge current, pulse-on time, pulse-off time and surfactant concentration. The ANOVA results tabulated in Table $\mathbf{8}$ show the contributions of the discharge current $(52.89 \%)$, the pulse-on time $(39.61 \%)$ and the concentration of surfactant $(6.07 \%)$, reducing the $S R$ considerably. It is found that the discharge current has a leading impact on the $S R$. It is observed from Figure 3 that an increase in the $S R$ takes place with an increase in the discharge current. The explanation for

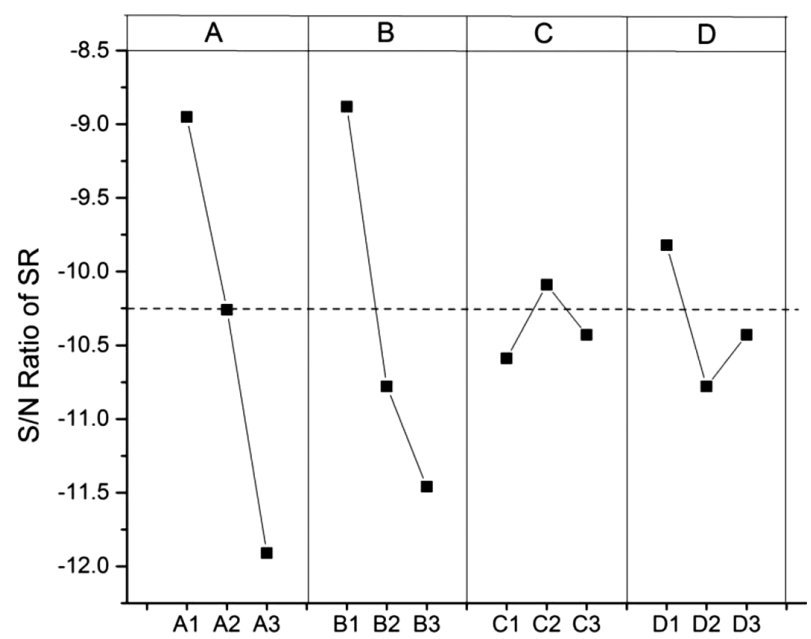

Figure 3: Main-effect plot for $S R$

Slika 3: Diagram glavnega učinka $S R$ this can be that an increase in the discharge current causes a corresponding increase in the spark energy, which results in the formation of deeper and larger craters and which, in turn, results in an increased surface roughness. The $S R$ increases with the increasing pulse-on time due to the fact that at a constant supply of current, the increase in the pulse-on time is proportional to the increase in the spark energy; subsequently, the melting boundary becomes wider and deeper and hence there is an increase in the SR value. ${ }^{36}$

Table 8: ANOVA of means for $S R \mathrm{~s}$

Tabela 8: ANOVA sredstva za $S R$

\begin{tabular}{|c|c|c|c|c|}
\hline Parameters & $\begin{array}{c}\text { Degree of } \\
\text { freedom } \\
(D F)\end{array}$ & $\begin{array}{c}\text { Sum of } \\
\text { squares }(S S)\end{array}$ & $\begin{array}{c}\text { Mean sum } \\
\text { of squares } \\
(M S S)\end{array}$ & $\begin{array}{c}\% \\
\text { contribution }\end{array}$ \\
\hline A & 2 & 13.138 & 6.569 & 52.89 \\
\hline B & 2 & 10.707 & 5.353 & 39.61 \\
\hline C & 2 & 0.389 & 0.194 & 1.53 \\
\hline D & 2 & 1.500 & 0.750 & 6.07 \\
\hline Total & 8 & 23.878 & & 100.00 \\
\hline
\end{tabular}

The pulse-off time is the least important factor and shows the smallest contribution as far as the $S R$ is concerned. This is due to the fact that no material is removed from the workpiece as there is no supply of the discharge current. It is observed that the pulse-off time increases with an increase in the SR. An increase in the surfactant concentration increases the surface roughness. This may be due to the fact that an increase in the surfactant concentration increases the dielectric conductivity, causing the spark energy to be more concentrated, which results in increased surface roughness. On the other hand, an increase in the surfactant concentration causes an increase in the dielectric conductivity and, at the same time, the dielectric fluid is mixed with the debris and tar particles accumulated in the machining gap..$^{35,37,38}$

\subsection{Multi-response optimisation of the parameter com- bination for the MRR and the SR based on the GRA}

Normalisation of the experimental data using Equations (3) and (4) is performed and considered in the range between $0-1$. The normalised data and the deviation sequence for each of the responses are listed in Table 9. A higher value of the response indicates a better performance and the higher normalised values that are equal to 1 depict the best performance. Hence, all the experimental values presented in Table 6 are substituted in Equations (3) and (4) to get the normalised values shown in Table 9. Typically, larger values of the $M R R$ and smaller values of the $S R$ are desirable for any machining operation. Thus, in the present work, the selected criterion for the $M R R$ is the larger the better and for the $S R$ it is the smaller the better.

These normalised-sequence values (data-processing values) are then substituted in Equation (5) and the Grey 
Table 9: Sequence of each performance characteristic after data pre-processing

Tabela 9: Zaporedje vsake lastnosti po predobdelavi podatkov

\begin{tabular}{|c|c|c|}
\hline \multirow{2}{*}{ Number } & \multicolumn{2}{|c|}{ Deviation sequences } \\
\cline { 2 - 3 } & $\begin{array}{c}\text { MRR (larger the } \\
\text { better) }\end{array}$ & $\begin{array}{c}\text { SR (smaller the } \\
\text { better) }\end{array}$ \\
\hline Ideal sequence & 1 & 1 \\
\hline 1 & 0 & 1.0000 \\
\hline 2 & 0.1069 & 0.8782 \\
\hline 3 & 0.2482 & 0.6548 \\
\hline 4 & 0.4550 & 0.9289 \\
\hline 5 & 0.5689 & 0.4619 \\
\hline 6 & 0.7792 & 0.4162 \\
\hline 7 & 0.8530 & 0.6345 \\
\hline 8 & 0.9887 & 0.1320 \\
\hline 9 & 1.0000 & 0.0000 \\
\hline
\end{tabular}

relational coefficient with the weights of $\xi M R R=0.5$ and $\xi S R=0.5$ is calculation using Equation (6). The grey relational grade is calculated using Equation (7) and the responses are presented in Table 10. Thus, the multi-criteria optimisation problem was transformed into a single equivalent objective function using the GreyTaguchi relational analysis. The higher the value of the Grey relational grade, the closer to the optimum value is the corresponding factor in the combination. Table 11 suggests that the highest value of the Grey relational grade was achieved for experiment no. 4. This result indicates that the best combination of the parameters for multiple responses among the nine experiments is $\mathrm{A}_{2} \mathrm{~B}_{1} \mathrm{C}_{2} \mathrm{D}_{2}$.

Table 10: Deviation sequences (Grey relational generating) Tabela 10: Odkloni sekvenc (Grey relacijsko generiranje)

\begin{tabular}{|c|c|c|}
\hline \multirow{2}{*}{ Number } & \multicolumn{2}{|c|}{ Deviation sequences } \\
\cline { 2 - 3 } & $\operatorname{MRR}\left(\Delta_{\mathrm{i}}\right) 1$ & $S R\left(\Delta_{\mathrm{i}}\right) 2$ \\
\hline Ideal sequence & 1 & 1 \\
\hline 1 & 1 & 0.0000 \\
\hline 2 & 0.8931 & 0.1218 \\
\hline 3 & 0.7518 & 0.3452 \\
\hline 4 & 0.5450 & 0.0711 \\
\hline 5 & 0.4311 & 0.5381 \\
\hline 6 & 0.2208 & 0.5838 \\
\hline 7 & 0.1470 & 0.3655 \\
\hline 8 & 0.0113 & 0.8680 \\
\hline 9 & 0.0000 & 1.0000 \\
\hline
\end{tabular}

A Grey-relational-response graph is shown in Figure 4 and its ANOVA analysis is shown in Table 12. The most significant factors contributing to the multiple responses are the discharge current $(33.79 \%)$, the pulse-on time $(34.59 \%)$, the pulse-off time $(22.28 \%)$ and the surfactant concentration $(9.34 \%)$. The results of Figure 4 indicate that the optimum parameter combination for these multiple responses is obtained for $A_{3} B_{1} C_{2} D_{1}$.
Table 11: Grey relational coefficient and grade for each performance Tabela 11: Grey relacijski koeficient in dosežena stopnja za vsako izvajanje

\begin{tabular}{|c|c|c|c|c|}
\hline \multirow{2}{*}{ Number } & \multicolumn{2}{|c|}{$\begin{array}{c}\text { Grey relational } \\
\text { coefficient }\end{array}$} & \multicolumn{2}{c|}{ Grey relational grade } \\
\cline { 2 - 5 } & $M R R$ & $S R$ & $\begin{array}{c}\text { Average } \\
\text { value }\end{array}$ & Rank \\
\hline 1 & 0.3333 & 1.0000 & 0.6667 & 4 \\
\hline 2 & 0.3589 & 0.8041 & 0.5815 & 6 \\
\hline 3 & 0.3994 & 0.5916 & 0.4955 & 9 \\
\hline 4 & 0.4785 & 0.8756 & 0.6770 & 1 \\
\hline 5 & 0.5370 & 0.4817 & 0.5093 & 8 \\
\hline 6 & 0.6937 & 0.4614 & 0.5775 & 7 \\
\hline 7 & 0.7728 & 0.5777 & 0.6753 & 2 \\
\hline 8 & 0.9780 & 0.3655 & 0.6717 & 3 \\
\hline 9 & 1.0000 & 0.3333 & 0.6667 & 5 \\
\hline
\end{tabular}

Table 12: ANOVA of means for Grey relational analysis

Tabela 12: ANOVA sredstva za Grey relacijsko analizo

\begin{tabular}{|c|c|c|c|c|}
\hline Parameters & $\begin{array}{c}\text { Degree of } \\
\text { freedom } \\
(D F)\end{array}$ & $\begin{array}{c}\text { Sum of } \\
\text { squares }(S S)\end{array}$ & $\begin{array}{c}\text { Mean sum } \\
\text { of squares } \\
(M S S)\end{array}$ & $\begin{array}{c}\text { \% con- } \\
\text { tribution }\end{array}$ \\
\hline A & 2 & 3.267 & 1.633 & 33.79 \\
\hline B & 2 & 3.343 & 1.671 & 34.59 \\
\hline C & 2 & 2.154 & 1.077 & 22.28 \\
\hline D & 2 & 0.903 & 0.451 & 9.34 \\
\hline Total & 8 & 9.667 & & 100.00 \\
\hline
\end{tabular}

\subsection{Confirmation test}

Conformation experiments were conducted for the optimum parameter combinations to verify the improvement in the responses. The results of the conformation experiments are compared with the outcome of the initial data and the predicated parameter combination based on the GRA (M. Kolli, A. Kumari ${ }^{19}$ ). Table 13 shows the results of the conformation experiments using the optimum surfactant-added EDM-process parameters ob-

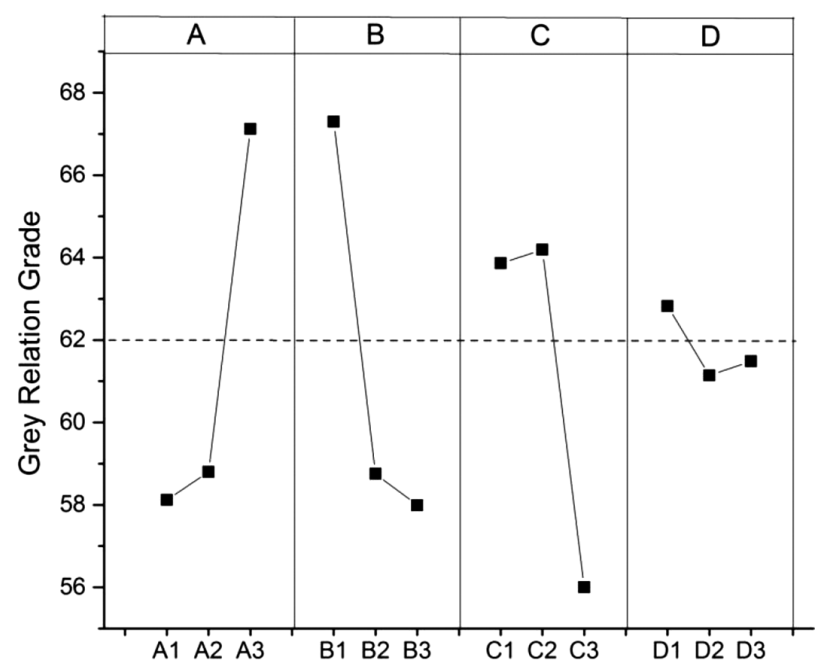

Figure 4: Process-parameter effect on Grey relational grade Slika 4: Učinek parametrov procesa na Grey relacijski razred 
tained using the GRA-Taguchi method, i.e., the initial data with combination $\mathrm{A}_{2} \mathrm{~B}_{1} \mathrm{C}_{2} \mathrm{D}_{3}$ and the optimum combination $\mathrm{A}_{3} \mathrm{~B}_{1} \mathrm{C}_{2} \mathrm{D}_{1}$. It is observed that the $M R R$ increased from 1.755 to $2.213 \mathrm{~mm}^{3} / \mathrm{min}$. However, the $S R$ was obtained in a considerable range. The corresponding percentage improvements in the $M R R$ and the $S R$ are $20.69 \%$ and $11.07 \%$, respectively.

Table 13: Results of the conformation experiment Tabela 13: Rezultati preizkusa skladnosti

\begin{tabular}{|c|c|c|c|}
\hline \multirow{2}{*}{ Observed values } & \multirow{2}{*}{$\begin{array}{c}\text { Orthogonal } \\
\text { array }\end{array}$} & $\begin{array}{c}\text { Optimum combination } \\
\text { level of machining } \\
\text { parameters }\end{array}$ \\
\cline { 3 - 4 } & & Prediction & Experiment \\
\hline Levels & $\mathrm{A}_{2} \mathrm{~B}_{1} \mathrm{C}_{2} \mathrm{D}_{3}$ & $\mathrm{~A}_{3} \mathrm{~B}_{1} \mathrm{C}_{2} \mathrm{D}_{1}$ & $\mathrm{~A}_{3} \mathrm{~B}_{1} \mathrm{C}_{2} \mathrm{D}_{1}$ \\
\hline$M R R$ & 1.755 & - & 2.213 \\
\hline$S R$ & 2.65 & - & 2.98 \\
\hline Grey relational grade & 67.70 & 69.18 & 70.45 \\
\hline
\end{tabular}

\subsection{Recast-layer thickness}

The EDM process is very complex due to rapid local heating causing an increase in the local temperatures, exceeding the melting point of the material, where

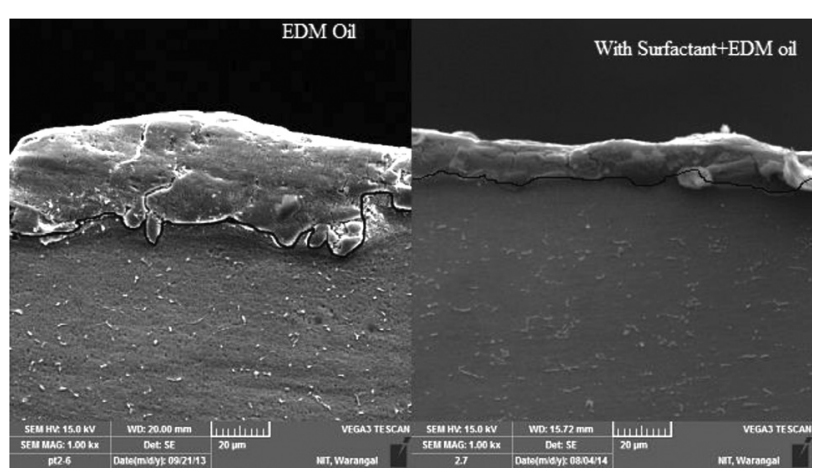

Figure 5: SEM micrographs of cross-sectional view of EDMed recast layer with surfactant and without surfactant: a) without EDM oil, b) with GRA surfactant at optimum conditions

Slika 5: SEM-posnetki prečnega prereza z EDM preoblikovano plastjo s površinsko aktivno snovjo in brez površinsko aktivne snovi: a) brez EDM olja, b) s površinsko aktivno snovjo GRA pri optimalnih pogojih

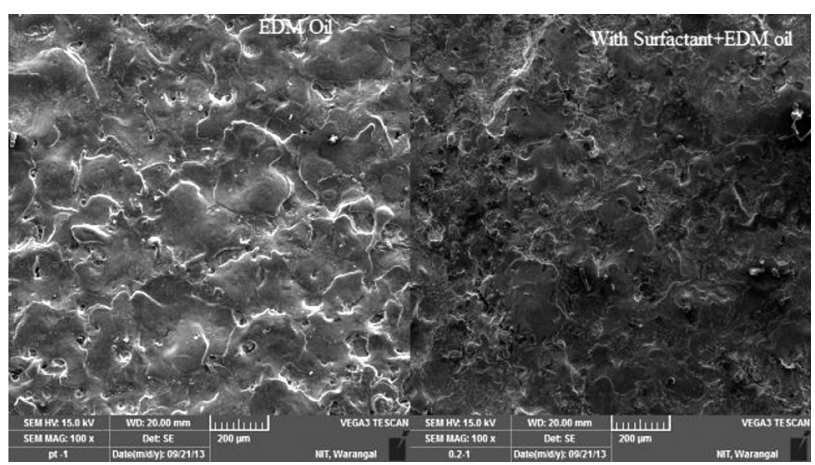

Figure 6: SEM micrographs of the machined samples: a) without surfactant and b) with the optimum GRA surfactant

Slika 6: SEM-posnetka obdelanih vzorcev: a) brez površinsko aktivne snovi in b) z optimalno površinsko aktivno snovjo GRA melting/vaporization is followed by rapid cooling and also by random attacks of the sparks. This results in surface damage in the form of cracks and generation of high thermal stresses exceeding the fracture strength of the material. It is also observed from Figure 5 that the $R L T$ decreases significantly with the surfactant added to the dielectric fluid. The addition of the surfactant to the dielectric improves its conductivity and lowers its viscosity, resulting in a smoother flow of the dielectric in the inter-electrode gap. As a result, the increase in the dreg-removal rate leads to improved flushing conditions. At the same time, an increase in the surfactant concentration in the dielectric results in a uniform distribution of discharge energy, which lowers the amount of the heat energy penetrating into the work surface and reducing the thickness of the recast layer.

\subsection{Surface micrographs}

Figure 6 shows SEM micrographs of the machined surfaces with and without the surfactant in the dielectric fluid. It is observed that the EDM process produces complex surfaces covered with globules of debris, large and small melted drops, pocket marks and cracks of various sizes. During the EDM process, some particles were eroded and attached to the material surface and the molten material was expelled randomly from the machining gap. As it can be seen from the figure, the surface structure is uneven. The size of the molten drops depends on the surfactant concentration, which is associated with a low $S R$ of the machined sample as shown in Figure 6b.

As discharge current is applied to the machining zone, equal-intensity discharge energy strikes the metal surface and a large quantity of the molten and flushed metal is suspended in the electrical-discharge gap, which results in a deterioration of the $S R$. Other reasons for a better surface finish of the machined surface are lower and smaller craters, cracks produced during the machining and generation of fewer micro-cracks because of the intense impulsive forces and stresses due to the equal-discharge energy. ${ }^{36}$

\section{CONCLUSION}

This paper presents an effective approach for the optimisation of the surfactant-added EDM of a titanium alloy. The process parameters were the discharge current, the pulse-on time, the pulse-off time and the surfactant concentration; the multi-optimization Grey-Taguchi approach was used. Based on the experimental results of the present study, the following conclusions are drawn:

- The MRR at the optimum condition (i.e., $\mathrm{A}_{3} \mathrm{~B}_{3} \mathrm{C}_{3} \mathrm{D}_{3}$ ) increases with the increase in the discharge current (20 A), the pulse-on time $(65 \mu \mathrm{s})$ and the surfactant concentration $(0.75 \mathrm{~g} / \mathrm{L})$. As the pulse-off time increases from 24 to $36 \mu$ s, the $M R R$ decreases, while beyond $36 \mu$ s the $M R R$ increases. 
- The optimum condition for the $S R$ was observed at $\mathrm{A}_{1} \mathrm{~B}_{1} \mathrm{C}_{2} \mathrm{D}_{1}$ having lower values of the discharge current $(10 \mathrm{~A})$, the pulse-on time $(25 \mu \mathrm{s})$ and the surfactant concentration $(0.25 \mathrm{~g} / \mathrm{L})$. It was observed that the $S R$ is directly proportional to the discharge current, the pulse-on time and the surfactant concentration.

- The optimum combination of the surfactant-added EDM parameters and their levels for the multi-performance characteristics of the surfactant-added EDM process are $A_{3} B_{1} C_{2} D_{1}$, the discharge current of $20 \mathrm{~A}$, the pulse-on time of $25 \mu \mathrm{s}$, the pulse-off time of $36 \mu$ s and the surfactant concentration of $0.25 \mathrm{~g} / \mathrm{L}$.

- All the process parameters significantly affect the multi-performance characteristics of the surfactantadded EDM process. However, the machining performance of the $M R R$ significantly increases from $1.755 \mathrm{~mm}^{3} / \mathrm{min}$ to $2.213 \mathrm{~mm}^{3} / \mathrm{min}$. The percentage contributions of various process parameters like the discharge current, the pulse-on time, the pulse-off time and the surfactant concentration are $(33.79$, $34.58,22.28$ and 9.34) $\%$, respectively.

- Fewer micro-cracks and even craters on the workpiece surface machined by EDM are formed when a surfactant is added to the dielectric fluid.

\section{REFERENCES}

${ }^{1}$ ASM International, Introduction to Titanium and Titanium alloys, Properties and selection: Nonferrous Alloys and Special Purpose Materials, Vol. 2, ASM Handbook, 1993

${ }^{2}$ E. O. Ezugwu, Z. M. Wang, Titanium alloys and their machinability - a review, Journal of Materials Processing Technology, 68 (1997) 12, 262-274, doi:10.1016/S0924-0136(96)00030-1

${ }^{3}$ C. H. C. Haron, A. Jawaid, The effect of machining on surface integrity of titanium alloy Ti-6Al-4V, Journal of Materials Processing Technology, 166 (2005) 5, 188-192, doi:10.1016/j.jmatprotec.2004. 08.012

${ }^{4}$ B. H. Yan, H. C. Tsai, F. Y. Huang, The effect in EDM of a dielectric of a urea solution in water on modifying the surface of titanium, International Journal of Machine Tools Manufacture, 45 (2005) 6, 194-200, doi:10.1016/ijmachtools.2004.07.006

${ }^{5}$ K. H. Ho, S. T. Newman, State of the art electrical discharge machining (EDM), International Journal of Machine Tools and Manufacture, 43 (2003) 13, 1287-1300, doi:10.1016/S0890-6955(03) $00162-7$

${ }^{6}$ K. L. Wu, B. H. Yan, J. W. Lee, C. G. Ding, Study on the characteristics of electrical discharge machining using dielectric with surfactant, Journal of Materials Processing Technology, 209 (2009) 8, 3783-3789, doi:10.1016/j.jmatprotec.2008.09.005

${ }^{7}$ A. S. Dukhin, P. J. Goetz, Ionic properties of so-called non-ionic surfactants in non-polar liquids, Dispersion Technology, Inc., New York 2004, 1-21

${ }^{8}$ A. S. Dukhin, P. J. Goetz, Evolution of water-in-oil emulsion controlled by droplet-bulk ion exchange: acoustic, electroacoustic, conductivity and image analysis, Dispersion Technology, Inc., New York 2012, 2, 1-15

${ }^{9}$ Kirk Othmer, Encyclopedia of chemical technology, Wiley, New York, 2004, 1-44

${ }^{10}$ S. L. Chen, B. H. Yan, F. Y. Huang, Influence of kerosene and distilled water as dielectrics on the electric discharge machining characteristics of Ti-6Al-4V, Journal of Materials Processing Technology, 87 (1999) 5, 107-111, doi:10.1016/S0924-0136(98) 00340-9
${ }^{11}$ S. K. Ho, D. K. Aspinwall, W. Voice, Use of powder metallurgy (PM) compacted electrodes for electrical discharge surface alloying/modification of Ti-6Al-4V alloy, Journal of Materials Processing Technology, 191 (2007) 4, 123-126, doi:10.1016/ j.jmatprotec.2007.03.003

${ }^{12}$ A. Hascalik, U. Caydas, A comparative study of surface integrity of Ti-6Al-4V alloy machined by EDM and AECG, Journal of Materials Processing Technology, 190 (2007) 10, 171-180, doi:10.1016/ j.jmatprotec.2007.02.048

${ }^{13}$ U. Caydas, A. Hascalik, Modeling and analysis of electrode wear and white layer thickness in die-sinking EDM process through response surface methodology, International Journal of Advance Manufacturing Technology, 38 (2007) 9, 1148-1156, doi:10.1007/ s00170-007-1162-1

${ }^{14}$ P. Fonda, Z. Wang, K. Yamazaki, Y. Akutsu, A Fundamental study on Ti-6Al-4V's thermal and electrical properties and their relation to EDM productivity, Journal of Materials Processing Technology, 202 (2008) 7, 583-589, doi:10.1016/j.jmatprotec.2007.09.060

${ }^{15}$ S. Abdulkareem, A. A. Khan, M. Konnch, Reducing electrode wear ratio using cryogenic cooling during electrical discharge machining, International Journal of Advance Manufacturing Technology, 45 (2009) 6, 1146-1151, doi:10.1007/s00170-009-2060-5

${ }^{16}$ A. T. Bozdana, O. Yilmaz, M. A. Okka, I. H. Filz, A comparative study on fast hole EDN of Inconel 718 and Ti-6Al-4V, 5th International conference and exhibition on Design and Production of machines and dies/moulds, Kusadasi, Aydin, Turkey, 2009

${ }^{17}$ Md. A. R. Khan, M. M. Rahman, K. Kadirgama, M. A. Maleque, M. Ishak, Prediction of surface roughness of Ti-6Al-4V in electrical discharge machining: a regression model, Journal of Mechanical Engineering and Sciences, 1 (2011) 9, 16-24

${ }^{18}$ M. M. Rahman, Modeling of machining parameters of Ti-6Al-4V for electric discharge machining: A neural network approach, Scientific Research and Essays, 7-8 (2012) 10, 881-890, doi:10.5897/SRE10. 1116

${ }^{19}$ M. Kolli, A. Kumar, Experimental investigation of surfactant mixed dielectric fluid for electric discharge machining of titanium alloy, International Colloquium on Materials, Manufacturing and Metrology, ICMMM 2014, IIT Madras, Chennai, India, 2014

${ }^{20}$ R. Jeyapaul, P. Shahabudeen, K. Krishnaiah, Quality management research by considering multi-response problems in the Taguchi method - a review, International Journal of Advanced Manufacturing Technology, 26 (2005) 7, 1331-1337, doi:10.1007/s00170-0042102-y

${ }^{21}$ J. Y. Kao, C. C. Tsao, S. S. Wang, C. Y. Hsu, Optimization of the EDM parameters on machining Ti-6Al-4V with multiple quality characteristics, International Journal of Advanced Manufacturing Technology, 47 (2010) 7, 395-402, doi:10.1007/s00170-009-2208-3

${ }^{22}$ L. Tang, Y. T. Du, Multi-Objective Optimization of Green Electrical Discharge Machining Ti-6Al-4V in Tap Water via Grey-Taguchi Method, Materials and Manufacturing Processes, 29 (2014) 7, 507-513, doi:10.1080/10426914.2013.840913

${ }^{23}$ M. Y. Lin, C. C. Tsao, H. H. Huang, C. Y. Wu, C. Y. Hsu, Use of the grey-Taguchi method to optimize the micro-electrical discharge machining (micro-EDM) of Ti-6Al-4V alloy, International Journal of Computer Integrated Manufacturing, 28 (2015) 6, 569-576, doi:10.1080/0951192X.2014.880946

${ }^{24}$ M. Kolli, A. Kumar, Parametric optimization of boron carbide powder added electrical discharge machining of titanium alloy, Applied Mechanics and Materials, 592-594 (2014), 678-683, doi:10.4028/www.scientific.net/AMM.592-594.678

${ }^{25}$ A. M. Nikalje, R. D. Gupta, A. Kumar, Analysis of recast layer and surface machined by Electrical Discharge Machining, International Conference on Recent Advances in Mechanical Engineering, Dr. M.G.R. Educational and Research Institute University, Chennai, India, 2012, 19-20 
${ }^{26}$ P. J. Ross, Taguchi techniques for quality engineering, McGraw-Hill, New York 1998, 24-98

${ }^{27}$ D. C. Montgomery, Design and analysis of experiments, Wiley, New York 1997, 395-476

${ }^{28}$ S. Phadke Madhav, Quality engineering using robust design, Prentice Hall, Englewood Cliffs, New Jersey 1989, 41-229

${ }^{29}$ C. L. Lin, J. L. Lin, T. C. Ko, Optimization of the EDM process based on the orthogonal array with fuzzy logic and grey relational analysis method, International Journal of Advanced Manufacturing Technology, 19 (2002) 7, 271-277, doi:10.1007/s001700200034

${ }^{30}$ Z. A. Khan, S. Kamaruddin, A. N. Siddique, Feasibility study of use of recycled high density polyethylene and multi response optimization of injection molding parameters using combined grey relational and principal component analysis, Materials \& Design, 31 (2010) 7, 2925-2931, doi:10.1016/j.matdes.2009.12.028

${ }^{31}$ Y. Y. Yang, J. R. Shie, C. H. Huang, Optimization of dry machining parameters for high purity graphite in end milling process, Materials and Manufacturing Processes, 21 (2006) 8, 838-845, doi:10.1080/ 03602550600728257

${ }^{32}$ G. Pankul, Z. A. Khan, Influence of slab milling process parameters on surface integrity of HSLA: a multi-performance characteristics optimization, International Journal of Advanced Manufacturing Technology, 61 (2012) 12, 859-871, doi:10.1007/s00170-011-3763-y
${ }^{33}$ A. M. Nikalje, A. Kumar, K. V. Sai Srinadh, Influence of parameters and optimization of EDM performance measures on MDN 300 steel using Taguchi method, International Journal of Advanced Manufacturing Technology, 69 (2013) 9, 41-49, doi:10.1007/s00170-0135008-8

${ }^{34}$ W. Konig, L. Jorres, Aqueous solution of organic compounds as dielectric for EDM sinking, Annals of the CIRP, 36 (1987) 5, 105-109, doi:10.1016/S0007-8506(07)62564-5

${ }^{35}$ K. L. Wu, B. H. Yan, J. W. Lee, C. G. Ding, Study on the characteristics of electrical discharge machining using dielectric with surfactant, Journal of Materials Processing Technology, 209 (2009), 3783-3789, doi:10.1016/j.jmatprotec.2008. 09.005

${ }^{36}$ A. Hascalik, U. Caydas, A comparative study of surface integrity of Ti-6Al-4V alloy machined by EDM and AECG, Journal of Materials Processing Technology, 190 (2007) 8, 173-180, doi:10.1016/ j.jmatprotec.2007.02.048

${ }^{37}$ R. Ji, Y. Liu, Y. Zhang, X. Li, Research of the rosin in machining fluid for electrical discharge machining, $16^{\text {th }}$ international symposium on electromachining, Shanghai, China, 19-23 April 2010

${ }^{38}$ Y. Zhang, Y. Liu, R. Ji, B. Cai, Y. Shen, Sinking EDM in water-in-oil emulsion, International Journal of Advanced Manufacturing Technology, 170 (2012) 11, 705-716, doi:10.1007/s00170-012-4210-4 